\title{
Editorial
}

\section{Habemus retrocesso?}

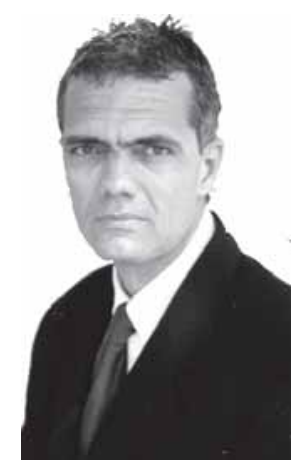

Prof. Dr. Marco Antonio Guimarães da Silva* marco@atlanticaedu.com.br

Nada como uma volta ao passado, para tentar prever ou pressupor as dificuldades que os que pensam e executam as pesquisas científicas terão pela frente, caso se confirme a postura ultraconservadora e radical de Joseph Ratzinger, carinhosamente apelidado pelo Daily Mirror como Gods Rottweiller (tradução propositalmente omitida).

Duas obras, "Carta a Cristina de Lorena (Lettera alla Sereníssima Madre Madama Cristina de Lorena, 1615, já referida por mim em editorial passado) e Carta sobre a Tolerância (Epistola de Tolerantia-, 1689)" escritas respectivamente por Galileu e Locke, talvez nos ofereçam alento para resistir a possíveis pressões obscurantistas.

A obra de Galileu, tida como manifesto programático da revolução científica, defende a cosmologia copernicana de sua aparente contradição com as Escrituras. A polêmica à época era se a teologia podia seguir sendo a mãe tutelar das ciências ou se estas podiam gozar de autonomia plena. Uma releitura de Locke nos permite idealizar uma ciência livre de pressões do estado ou da igreja. Sua Carta é uma reivindicação e homenagem filosófica à liberdade de consciência e à liberdade religiosa, representando uma continuidade da legitimação da liberdade que já havia sido preconizada por Spinoza em seu Tratado teológico político.

Com rigor e ordem metodológica, Locke estabelece a ordem das sociedades civil e religiosa, deixando claro que todo intento de confundir ambas as ordens sinaliza para intolerâncias que prejudicam a liberdade individual e o bem estar geral. Ao definir o Estado como sendo uma sociedade de homens constituída para conservar e promover somente os bens civis (a vida, a liberdade, a integridade corporal e a propriedade privada) e a igreja como uma sociedade de homens que se reúnem espontaneamente para honrar publicamente a Deus, do modo que melhor julgarem para agradar a divindade e assim obterem a salvação de suas almas, o filósofo nos leva às seguintes conclusões: o Estado tem o dever de respeitar a liberdade da consciência humana, a liberdade de credo, a liberdade de culto de todas as religiões e a Igreja não deve interferir nos bens civis ou fazer uso da força, porque esta última sempre prejudica a aspiração de salvação do ser humano.

Estariam o Estado e a Igreja mantendo a isenção preconizada por Locke em suas áreas de atuação? Estaria o "Estado" sendo influenciado pela Igreja, ao restringir as pesquisas com células tronco, ao dificultar outras investigações cientificas na área da genética e ao tentar impedir que o paciente tenha livre arbítrio à hora da própria morte? Todos sabemos a resposta.

$O$ perigo ainda maior estaria em dirigentes que se deixam influenciar por teorias retrógradas e passam eles mesmos a representar um duplo poder: o do Estado e da Igreja. Um temível exemplo está na redescoberta do Criacionismo (teoria da origem dos seres por criação, oposta à evolução espontânea), que ganha corpo mais expressivamente no sul dos Estados Unidos e já se manifesta timidamente em algumas regiões do Brasil. Os inimigos declarados de Darwin têm a simpatia e até mesmo o incentivo de governadores e presidentes e vêm impondo, às crianças e jovens, um modo de pensar e viver digno do mais obscuro período da humanidade.

Em um mundo em risco de ser totalmente dominado por esses neofundamentalistas cristãos, ponho me a pensar que fim levaria o progresso cientifico explicado à luz dos preceitos das quebras de paradigmas defendida por Kuhn (Thomas Samuel, 1922-1966) ou justificado sob a forma critica, mediante conjeturas e refutações, de Popper (Karl Raimund, 1902-1944). Obviamente o progresso científico não existiria e todos teríamos que rever as nossas perspectivas sonhadoras em poder assistir, ainda nesta geração, a cura do diabetes ou de alguns tipos de câncer, além da prevenção de cardiomiopatias e de outras inúmeras enfermidades.

Sendo inevitável fugir de influências religiosas sobre o poder estatal, melhor seria que a Igreja católica, menos dogmática e mais adaptada às conquistas e avanços científicos e tecnológicos que o presente/futuro nos reserva, pela força que tem, influenciasse o Estado e até mesmo outras religiões, e assumisse o papel chave na saúde e bem estar da sociedade. Oxalá estejamos equivocados com a previsões feitas sobre o Papado que agora se inicia. Quem sabe o Santo Padre, um dia, ao acordar, se inspire, auxiliado pela luz primaveril que já insiste em substituir o cinza do recém finado inverno romano, e tome a seguinte decisão: a partir de hoje não mais obstaculizaremos os avanços científicos e as reformas sociais dos paises emergentes. Afinal, conclui ele: resolvi ter um rebanho mais saudável, feliz, sem culpas e receios de ter vindo parar neste confuso planeta e, sobretudo, sem medo de, ao morrer, ter que enfrentar o tédio de um purgatório ou o excessivo calor de um inferno.

Céu para todos! Vivas para o Papa e para a santa e milenar paciência do homem!! Vade Retrum retrocesso! 